\title{
Micronutrient Status and its Correlation with Chemical Properties of Soils of Gaganbawda Tehsil of Kolhapur District, Maharashtra
}

\author{
Sayli T. Waghmare, Shital B. Pawar* and Raghunath V. Kulkarni \\ Department of Soil Science and Agriculture Chemistry, College of Agriculture, \\ Kolhapur, Maharashtra, India \\ *Corresponding author
}

\begin{abstract}
A B S T R A C T
Keywords

Micronutrient, Chemical properties in soils, Auxian production, DTPA solution, $\mathrm{Fe}, \mathrm{Mn}$,

$\mathrm{Zn}, \mathrm{Cu}$

\section{Article Info}

Accepted: 08 December 2020 Available Online: 10 January 2021

Studies were conducted to know the status of available micronutrient in relation to chemical properties in soils of Gaganbawda tehsil of Kolhapur district. For this purpose 85 surface soil samples were collected from 39 villages. Data show that these soil were 100 per sufficient in $\mathrm{Fe}, \mathrm{Mn}$ and $\mathrm{Cu}$ but 84.89 per cent sufficient and 14.11 per cent deficient in zinc. The soils were strongly acidic to slightly acidic in reaction, normal in EC, barely calcareous to moderately calcareous and moderate to very high in organic carbon. Data shows that DTPA extractable Mn was significantly and negatively correlated with $\mathrm{pH}\left(-0.249^{*}\right)$. Mn had significant and positive correlation with EC $\left(0.239^{*}\right)$. Zn possessed negative and significant correlation with organic carbon $\left(-0.245^{*}\right)$. Copper did not exhibit significant correlation with chemical properties.
\end{abstract}

\section{Introduction}

The micronutrients are essential for the proper biochemical transformation within plant body, so as to yield the desired end product, $\mathrm{Fe}$ helps in photosynthesis while, $\mathrm{Mn}$ is essential for photosynthesis, carbon assimilation and nitrogen metabolism. $\mathrm{Zn}$ is essential for protein and auxian production, $\mathrm{Cu}$ is a constituent of cytochrome oxidase. Every micro-nutrient element plays an important role in plant growth. Their significance in physiological processes and plant metabolism is equally important. Iron, manganese, zinc and copper are essential micro-nutrients for plant growth through their involvement in various enzymes and other physiologically active molecules, these micronutrients are important for gene expression, biosynthesis of proteins, nucleic acids, growth substances, chlorophyll and secondary metabolites, metabolism of carbohydrates and lipids, stress tolerance, etc. Soil fertility is one of the important factors controlling yield of crops characterization in relation to evaluation of fertility status of soil of an area is important 
aspect. Keeping these view and also lack of information on micronutrient status to identify the emerging micronutrient deficiency or toxicity in soils, therefore a comprehensive study was undertaken by using GPS-GIS for evaluation of micronutrient status of soils and their relation with chemical properties of soils of Gaganbawda tehsil.

\section{Materials and Methods}

The geographical area of tehsil is 28228 ha. It belongs to western region Maharashtra state and located between 160 54' 35.05" north latitude and 730 90' 45.5', east longitude, elevation $80 \mathrm{~m}$ from mean sea level. Gaganbawda is situated on the Sahyadri range and fifty five kilometer away from Kolhapur, is non developed, forest and hilly area of district. The climate of Gaganbawda tehsil is hot in summer. During summer highest day temperature is in between $340 \mathrm{C}$ to $420 \mathrm{C}$. Annual average Rainfall is approximately 5000-6000 mm. Total 85 surface samples were collected from 39 villages along with GPS-GIS reading. The processed soil samples were analyzed for their chemical properties as per standard methods suggested by Jackson (1978). The micronutrients in soil samples were extracted with DTPA solution (Linsday and Norvell, 1978) determined with the help of atomic absorbption spectrophotometry.

\section{Results and Discussion}

\section{DTPA extractable Iron}

The DTPA extractable Fe ranged from 11.00 to $60.50 \mathrm{mg} \mathrm{kg}^{-1}$ (sufficient) with the mean value of $41.20 \mathrm{mg} \mathrm{kg}^{-1}$ (sufficient). All the soils showed sufficiency in iron content, that is above critical level $\left(4.5 \mathrm{mg} \mathrm{kg}^{-1}\right)$ Takkar et $a l .$, (1989). The sufficiency of available iron might be due to heavy rainfall leaches to the process of laterization and raw organic matter content. Pharande et al., (1996) also reported the similar results in Alfisols of western Maharashtra. Thombare (2014) found similar results in the soils of Hatkangale tehsil of Kolhapur district. All the soils were sufficient in $\mathrm{Fe}$ as the amount of iron required by the crops is being released by iron bearing minerals in these soils.

High Fe content in soil may be due to presence of minerals like magnetite, hematite and limonite which together constitute bulk of trap rock in these soils, the similar result were reported by Mandavgade et al., (2015) for the soils of Jintu, Selu and Pathri tehsils of Parbhani district, Maharashtra.

\section{DTPA extractable Manganese}

DTPA extractable $\mathrm{Mn}$ ranged from 11.68 to $40.60 \mathrm{mg} \mathrm{kg}^{-1}$ (sufficient) with the mean value of $27.18 \mathrm{mg} \mathrm{kg}$ (sufficient). All the soils showed sufficiency in Mn content above critical level (2.0 mg kg-1) (Takkar et al, 1989). The sufficiency of maganese in soils might be due to the higher amount of ferromagnesium content and optimum soil moisture content. Waghmare and Takankar (2007) in soils of Nilanga tehsil of Latur district (Maharashtra).

\section{DTPA extractable Zinc}

The DTPA extractable $\mathrm{Zn}$ ranged from 0.12 to $3.94 \mathrm{mg} \mathrm{kg}^{-1}$ with a mean value $1.37 \mathrm{mg}$ $\mathrm{kg}^{-1}$. 85.89 per cent soils were sufficient in $\mathrm{Zn}$ content which is above critical level $0.6 \mathrm{mg}$ $\mathrm{kg}^{-1}$ (Katyal and Randhva, 1983) and 14.11 per cent soils were deficient in $\mathrm{Zn}$ content. The sufficiency of zinc due to moderately acidic $\mathrm{pH}$ and moderate organic carbon parent material might be containing zinc bearing minerals. Also deficiency due to zinc exist in reduced form. Similar result were recorded by Haribhushan et al., (2013) and Minakshi et al., (2005). 
Table.1 Status of DTPA Extractable micronutrients content

\begin{tabular}{|c|c|c|c|c|}
\hline \multirow{2}{*}{ Particular } & \multicolumn{4}{|c|}{ Available micronutrient (mg kg $\left.{ }^{-1}\right)$} \\
\cline { 2 - 5 } & Fe & $\mathbf{M n}$ & $\mathbf{Z n}$ & $\mathbf{C u}$ \\
\hline Range & $11.00-60.50$ & $11.68-40.60$ & $0.12-3.94$ & $0.36-11.00$ \\
\hline Mean & 41.20 & 27.18 & 1.37 & 4.07 \\
\hline Critical limit & 4.5 & 2.0 & 0.6 & 0.2 \\
\hline Sufficient & $85(100 \%)$ & $85(100 \%)$ & $73(85.89 \%)$ & $85(100 \%)$ \\
\hline Deficient & - & - & $12(14.11 \%)$ & - \\
\hline $\mathbf{9 5 \%}$ confidence limit & 49.5 & 28.92 & 3.82 & 10.64 \\
\hline
\end{tabular}

Table.2 Correlation of chemical properties with DTPA extractable micronutrients

\begin{tabular}{|c|c|c|c|c|}
\hline \multirow{2}{*}{$\begin{array}{c}\text { Chemical } \\
\text { properties }\end{array}$} & \multicolumn{3}{|c|}{ DTPA extractable micronutrients $\left(\mathbf{m g ~ k g}^{-\mathbf{1}}\right)$} \\
\hline pH & -0.205 & $-0.249^{*}$ & 0.190 & $\mathbf{C u}$ \\
\hline $\mathbf{E C}$ & 0.121 & $0.239^{*}$ & 0.201 & 0.164 \\
\hline $\mathbf{O C}$ & -0.151 & -0.203 & $-0.245^{*}$ & -0.178 \\
\hline $\mathbf{C a C O}_{3}$ & 0.170 & 0.121 & 0.119 & 0.144 \\
\hline
\end{tabular}

*and**Significance of values at $\mathrm{P}=0.05$ and 0.01 , respectively

Fig
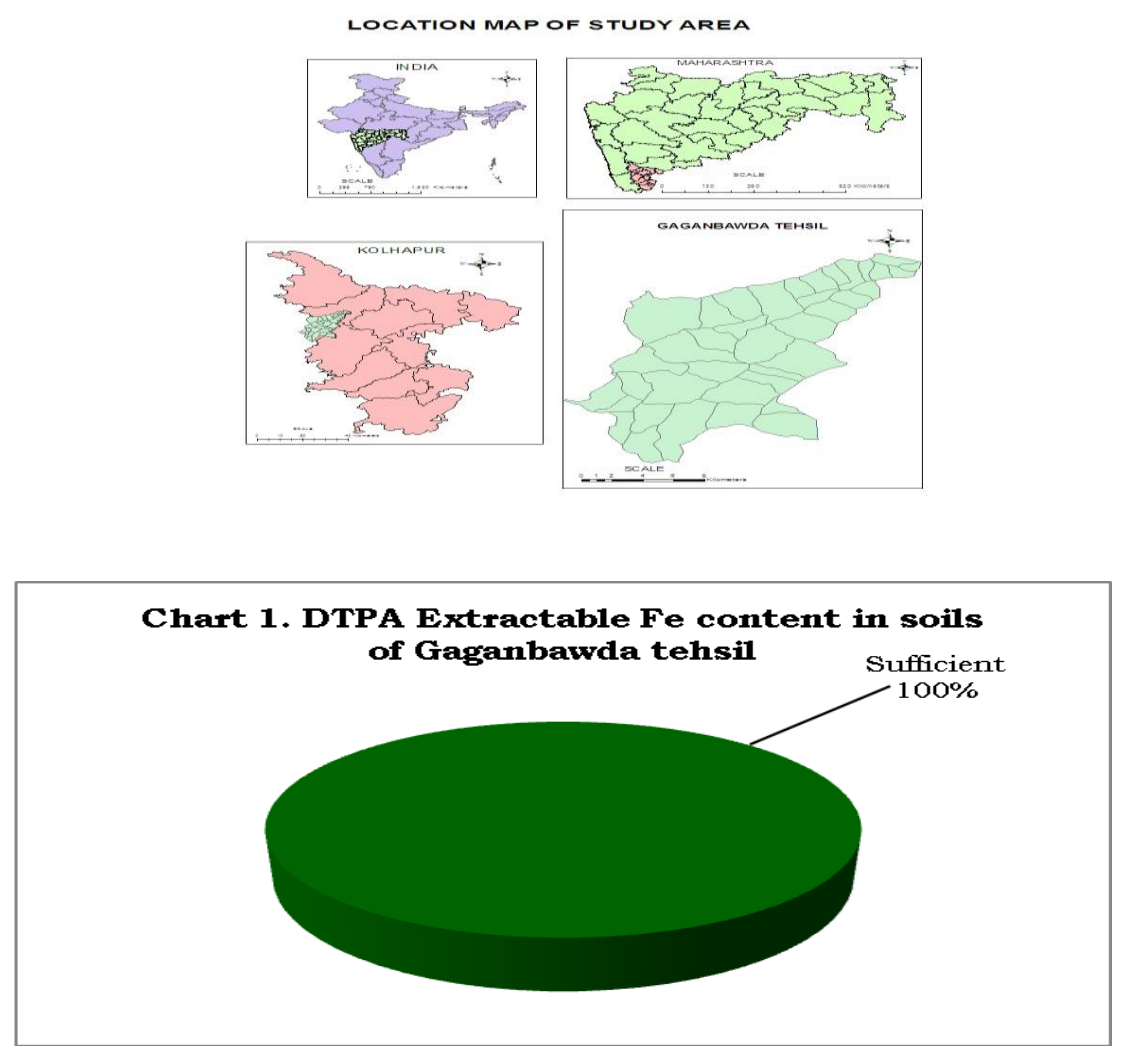
Chart 2. DTPA Extractable Mn content in soils of Gaganbawda tehsil

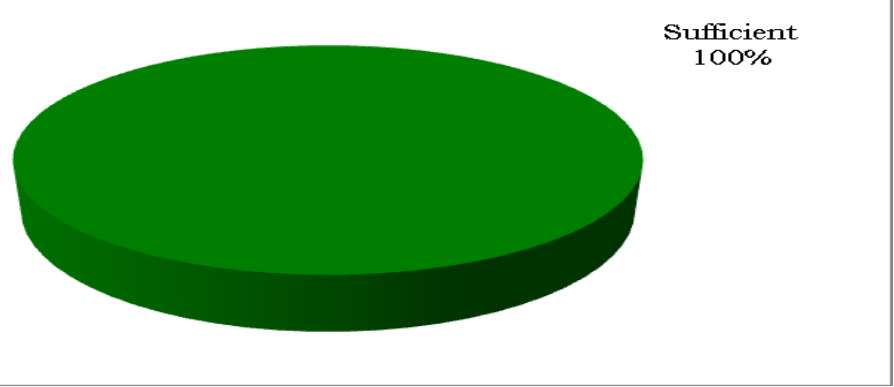

Chart 3. DTPA Extractable Zn content in soils of Gaganbawda tehsil

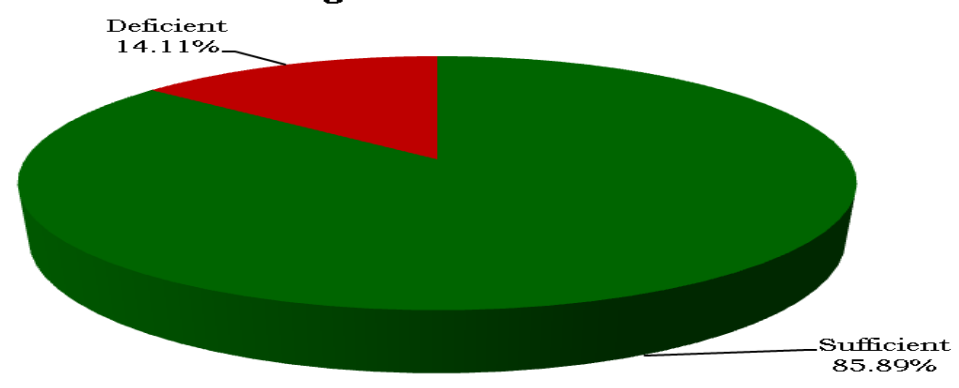

Chart 4. DTPA Extractable Cu content in soils of Gaganbawda tehsil Sufficient

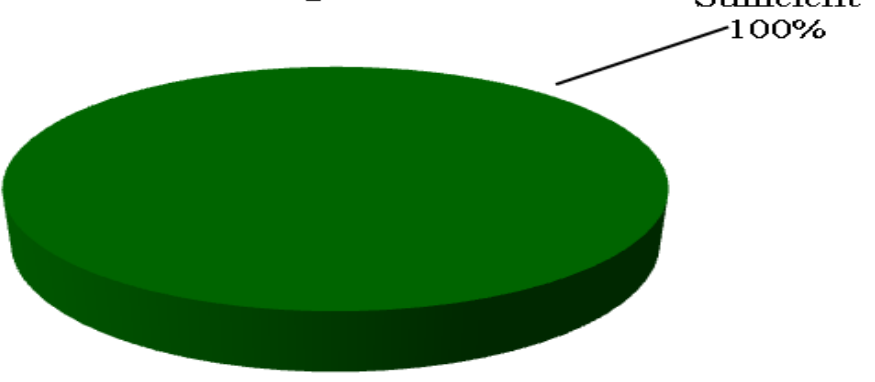

Chart 5. pH of soils of Gaganbawda tehsil

Slightly acidic Strongly

$4.70 \%$

acidic

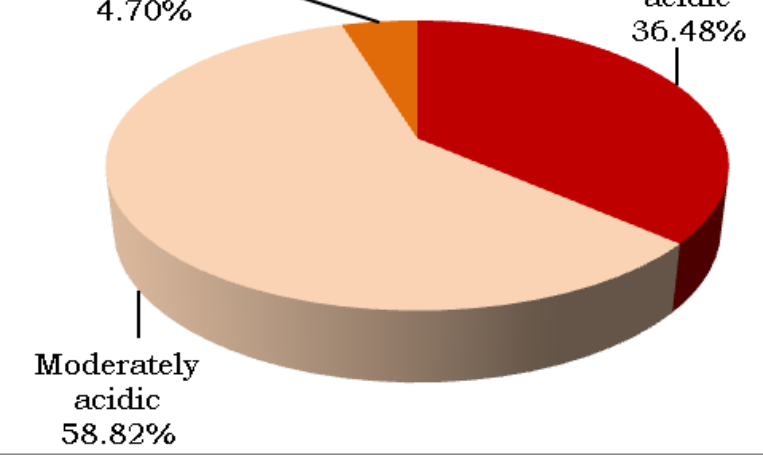



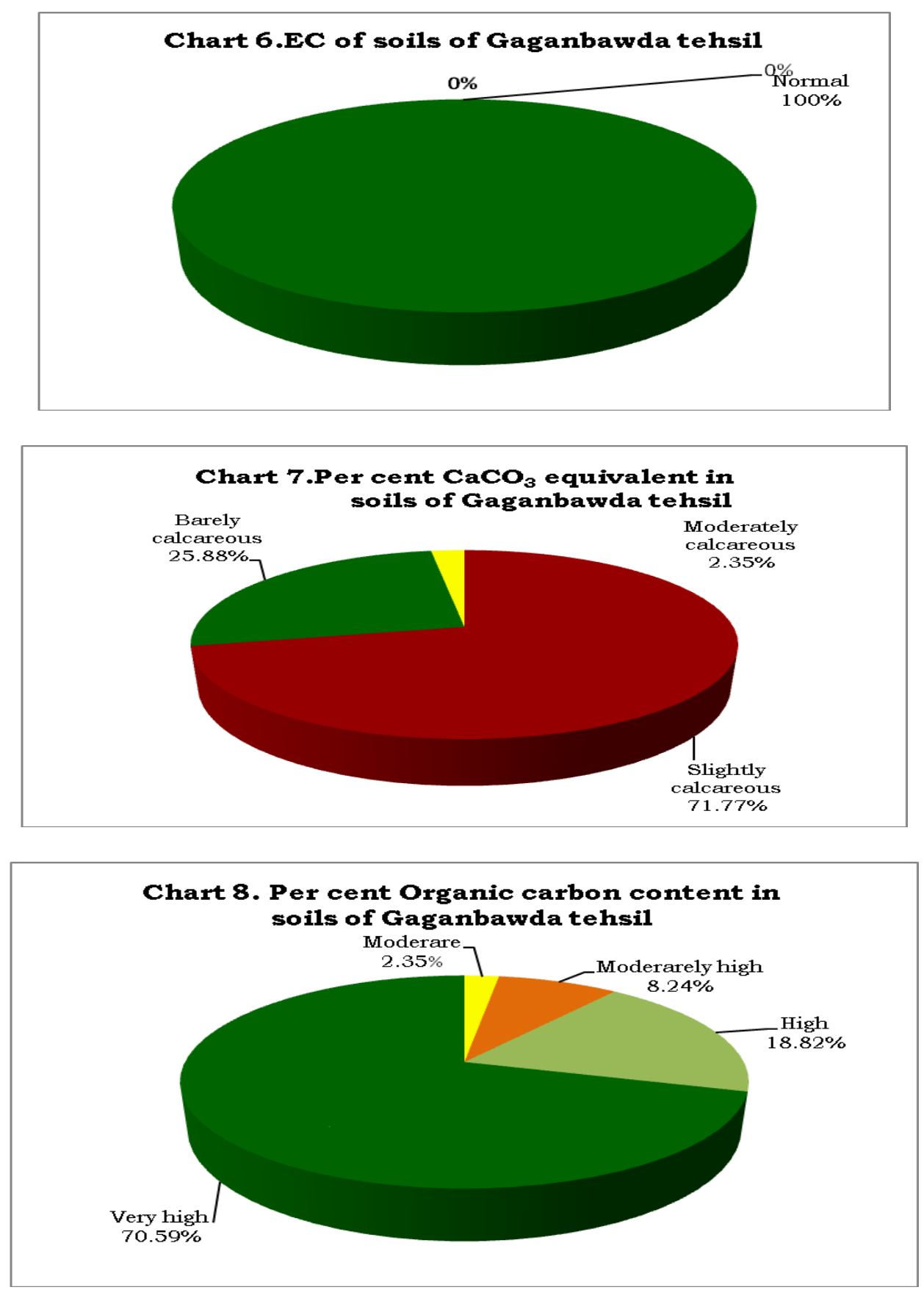

\section{DTPA extractable Copper}

The DTPA extractable $\mathrm{Cu}$ ranged from 0.36 to $11.00 \mathrm{mg} \mathrm{kg}^{-1}$ (sufficient) with mean value $4.07 \mathrm{mg} \mathrm{kg}^{-1}$ (sufficient). All soil samples were sufficient in DTPA extractable copper in soil. Copper content of soil is above crticial level i.e. $0.2 \mathrm{mg} \mathrm{kg}^{-1}$ (Katyal and Randhava, 1983). This might be due to presence of $\mathrm{Cu}$ minerals like Cuprite and Chalcosite etc. in parent material. The similar results have been reported by Waghmare and Takankar (2007) in Nilanga tehsil of Latur district (Maharashtra). The higher amount of DTPA extractable $\mathrm{Cu}$ in surface layer might be due to higher biological activities and chelating effect. Similar result were reported by Thakre et al., (2013) in Wardha region, India. 


\section{Chemical properties of soil}

The $\mathrm{pH}$ of the soils of Gaganbawda tehsil of Kolhapur district ranged from 4.86 to 6.94 . The soils were strongly acidic to slightly acidic in reaction. Among the soil samples tested, 31 samples (36.48 Per cent) were strongly acidic, 50 samples (58.82 Per cent) were moderately acidic, 4 samples (4.70 Per cent) were slightly acidic in nature the acidic reaction of maximum soil of the tehsil might be due to slopy land and undulating topography, high rainfall leading to leaching losses of bases from the surface soils and accumulation of iron oxides and sesquioxide. The similar results were also recorded by Mishra et al., (2014).

The EC of soils of Gaganbawda tehsil were ranged from 0.10 to $0.32 \mathrm{dSm}^{-1}$ with average mean value $0.15 \mathrm{dS} \mathrm{m}^{-1}$ (normal). These observation indicate that, all the 100 per cent soils were normal, non-saline in nature and suitable for healthy plant growth. The low EC may be due to low temperature, high humidity, light texture of soil, heavy rainfall, high erosion and leaching down of soluble salts. Singh et al., (2009) also reported the similar finding in Hoshangabad district of Madhya Pradesh.

Per cent calcium carbonate equivalent content in soils of Gaganbawda Tehsil of ranged from 0.37 to 2.25 per cent categorized as barely calcareous to moderately calcareous with the mean value 1.31 per cent (slightly calcareous). 25.88 per cent soils were barely calcareous, 71.77 per cent soils were slightly calcareous and 2.35 per cent soils were moderately calcareous.

The low calcium carbonate content of soils may be due to low temperature, porous nature of soil, heavy rainfall, high humidity and erosion leads to rapid leaching down of soluble salts and soils basic cations. The similar results were recorded by and Singh and Kundu (2010) for north eastern India.

The organic carbon status of soil ranged from 0.58 to 1.80 per cent categorized into moderate to very high with the mean value 1.20 per cent (very high). 2.35, 8.24, 18.82, 70.59 per cent soil samples under moderatre, moderately high, high and very high category respectively. This might be due to addition of FYM, low temperature, high rainfall, accumulation and decomposition of leaves, organic residues and litters. The low organic carbon content in the soils may be attributed to poor management practices such as lack of addition of crop residues and organic manures. Besides this, intensive cropping is also one of the reason for low organic carbon content. The high content of organic carbon might be due to the addition of organic manures through either artificially or naturally and its subsequent decomposition. (Mandavgade et al., 2015).

\section{Correlation between chemical properties and available nutrients}

Manganese showed negative significant correlation with $\mathrm{pH}\left(\mathrm{r}=-0.249^{*}\right)$. Chaudhari et al., (2013) found similar results as significant negative correlation with DTPA extractable micronutrient $\mathrm{Mn}$ which is evident from ' $r$ ' value of $-0.607^{*}$. DTPA extractable manganese showed highly significant positive correlation with $(\mathrm{r}=0.239 *)$.Chaudhari et al., (2012) found similar results as significant positive correlation between manganese and electrical conductivity $(r=0.9284)$. The similar result reported by Chaudhari et. al.(2013) found similar significant positive correlation between EC and Mn ( $r=0.2387)$

Zinc content of soils indicates the negative significant correlation with zinc $\left(r=-0.245^{*}\right)$ Mondal et al., (2015) revealed that DTPA extractable zinc has negative significant 
correlation with organic carbon $(\mathrm{r}=-0.578 * *)$ in soils of Jammu district. Available iron and zinc did not show any significant correltation with any chemical properties.

In conclusion the soils of Gaganbawda tehsil were sufficient in DTPA extractable iron, manganese and copper but zinc was deficient in $14.11 \%$ soil samples. The soil was strongly acidic to slightly acidic in reaction and normal in salt content, moderate to very high in organic carbon content and barely calcareous to moderately calcareous in per cent calcium carbonate equivalent. The manganese showed negative significant correlation with $\mathrm{pH}$. The manganese of soils showed highly significant positive correlation with EC. Zinc content showed negative significant correlation with organic carbon. The copper and iron had no significant correlation with any chemical properties.

\section{References}

Chaudahri, P.R., Ahire, D.V. and Vidya 2012.Correlation between Physicochemical properties and available nutrients in sandy loam soils of Haridwar region.J. Chemical, Biological andPhysical Sciences, 3, 1493-1500

Chaudhari, P.R., Ahire, D.V. and Vidya.2013. Relationship among electrical conductivity, soil properties and available nutrients in the soil of north Maharashtra region. J. Chemical, Biological and Physical Sciences.3(1),5-8.

Haribhushan Athokpam, Shabir Hussain Wani, David Kamei, Herojit Singh Athokpam, Jyotsna Nongmaithem, Deepak kumar. and Lamalakshmi Devi.2013. Soil macro and micro nutrient status of Senapati district, Manipur. African. Agric. Research.8(39),4932-4936.
Katyal, J.C. and Randhawa, N.S. 1983. In micronutrient FAO Fertilizer and Plant Nutrition Bulletin, Rome, 5,92.

Lindsay, W.L. and Norvell, W.A. 1978. Development of DTPA soil test for Zn, $\mathrm{Fe}, \mathrm{Mn}$, and $\mathrm{Cu}$. Soil Science AmericanJournal .42,421-426.

Mandavgade, R.R., Waikar, S.L., Dhamak, A.L. and Patil, V.D.2015. Evaluation of micronutrient status of soils and their correlation with some chemical properties of soils of northern tehsils (Jintur, Selu and Pathri) of Parbhani district. IOSR J. Agril. and Vet. Sci.8(2), 38-41.

Minakshi, N.S., Tur, Nayyar, V.K., Sharma, P.K. and Sood, A.K. 2005. Spatial Distribution of micro nutrients in soils of Patiala District. A GIS Approach. J. Indian Soc. Soil Sci., 53 (3), 324-329.

Mishra, A., Pattnaik, Truptimayee, Das, D. and Mira Das.2014. Soil fertility maps preparation using GPS and GIS in Dhenkanal District, Odisha, India. International Journal of Plant and Soil Science.3(8), 986-994.

Mondal, A.K., Rai, P.W. and Kumar, M.2015. Available Micronutrient status and their relationship with soil properties vegetables growing area of Jammu district. Progressive Horticulture. 47(1), 95-98

Pharande, A.L., Rasker, B.N. and Nipunage, M.U.1996. Micronutrient status of important Vertisols and Alfisols soil series of Western Maharashtra. J.Maharashtra Agric. Univ.21 (2), 182185.

Singh, K.N., Abhishek Rathore., Tripathi, A.K., Subba Rao, A. andSalman Khan.2009.11 ${ }^{\text {th }}$ ESRI India userconference.1-11.

Singh, R. and Kundu, D.K. 2010. Physicochemical and Hydraulic characteristics of soils of major sub group of Eastern India. J. Indian Soc. Soil Sci.,58 (3), 
267-278.

Takkar, P.N., Chhibba, I.M. and Mehta, S.K. 1989.Twenty years of coordinated research on micro-nutrients in soils and plants. Bull. Indian Ins. Soil Sci.1,76.

Thakre, Y.G., Choudhary, M.D. and Raut, R.D. 2013.Available micronutrient cation status of red soils in Wardha region. J. Chemical and PharmaceuticalResearch.5(8),64-68.

Thombare, P.C. 2014.GPS-GIS based soil fertility maps of 'Hatkanangle' Tehsil of Kolhapur district (M. S.) M. Sc.
(Agri.) Thesis, M. P. K. V., Rahuri. Waghmare, M.S. and Takankar, V.G. 2017.Status of available nutrients in soils of Nilanga tehsil of Latur distirct (Maharashtra) paper presented in state level seminar on soil health enhancement for food and environmental security, organized by PCISSS, at Marathwada Agril. University Parbhani. Oct. 12 and 13, Abst. pp. 2.

\section{How to cite this article:}

Sayli T. Waghmare, Shital B. Pawar and Raghunath V. Kulkarni. 2021. Micronutrient Status and its Correlation with Chemical Properties of Soils of Gaganbawda Tehsil of Kolhapur District, Maharashtra. Int.J.Curr.Microbiol.App.Sci. 10(01): 552-559. doi: https://doi.org/10.20546/ijcmas.2021.1001.067 